\title{
Pelatihan Kader Posyandu dalam Pembuatan Biskuit Kaya Protein Ikan di Desa Cileles, Jatinangor, Sumedang
}

\section{(Posyandu Cadres Training in Fish Protein Rich Biscuit Preparation in Cileles Village, Jatinangor, Sumedang)}

\author{
Junianto ${ }^{1^{*}}$, Zahidah ${ }^{2}$, Kiki Haetami ${ }^{3}$ \\ ${ }^{1}$ Kelompok Keilmuan Pengolahan Hasil Perikanan, Fakultas Perikanan dan Ilmu Kelautan, Universitas Padjadjaran, \\ Kampus Jatinganor, Jatinangor 45363. \\ 2 Kelompok Keilmuan Manajemen Sumberdaya Perikanan, Fakultas Perikanan dan Ilmu Kelautan, Universitas Padjadjaran, \\ Kampus Jatinganor, Jatinangor 45363. \\ ${ }^{3}$ Kelompok Keilmuan Budidaya Perikanan, Fakultas Perikanan dan Ilmu Kelautan, Universitas Padjadjaran, \\ Kampus Jatinganor, Jatinangor 45363. \\ *Penulis Korespondensi: junianto@unpad.ac.id \\ Diterima Desember 2020/Disetujui September 2021
}

\begin{abstract}
ABSTRAK
Peran Ibu sangat penting dalam peningkatan konsumsi protein ikan untuk balita dan anak-anak. Konsumsi protein ikan sangat berguna untuk menjaga kesehatan, mempercepat tumbuh kembang anak, dan peningkatan kecerdasan. Program ini bertujuan untuk memberikan pengetahuan dan melatih keterampilan dalam pembuatan biskuit kaya protein ikan melalui fortifikasi tepung daging ikan nilem kepada ibu-ibu posyandu sebagai khalayak sasaran di Desa Cileles, Kecamatan Jatinangor, Kabupaten Sumedang. Kegiatan ini berlangsung selama tujuh bulan yaitu dari bulan Mei-Desember 2020. Metode yang digunakan adalah pelatihan pembuatan biskuit kaya protein ikan. Berdasarkan hasil kegiatan yang telah dilakukan disimpulkan bahwa pengetahuan dan keterampilan ibu-ibu posyandu dalam pembuatan biskuit kaya protein ikan yang difortifikasi dengan tepung daging ikan nilem telah ada peningkatan. Produk yang dihasilkan secara organoleptik disukai oleh panelis.
\end{abstract}

Kata kunci: biskuit, pelatihan, posyandu, tepung daging ikan nilem

\begin{abstract}
The role of mothers is very important in increasing the consumption of fish protein for toddlers and children. Consumption of fish protein is very useful for maintaining health, accelerating growth and development of children, and increasing intelligence. The aim of this program is to provide knowledge and train skills in making biscuits rich in fish protein fortified with nilem fish meat flour to Posyandu women as the target audience in Cileles Village, Jatinangor Subdistrict, Sumedang District. This activity lasts for seven months, from May to December 2020. The methods used training in making fish potein - rich biscuit. Based on the results of the activities that have been carried out, it can be concluded that posyandu caders have been knowledge and skills in making fish protein-rich biscuits fortified with nilem fish meat flour. Organoleptically produced products are preferred by panelis.
\end{abstract}

Keywords: biscuits, nilem fish meat flour, posyandu, training

\section{PENDAHULUAN}

Desa Cileles merupakan desa yang berbatasan langsung dengan kampus Universitas Padjadjaran (Unpad), Jatinangor. Letak desa ini tepat berada di bagian belakang kampus. Masyarakatnya sebagian besar berprofesi sebagai petani penggarap dan juga buruh pabrik. Umumnya seperti masyarakat dekat kampus, banyak tempat kost dan apartemen, yang mana pemiliknya bukan orang asli Desa Cileles. Kegiatan ibu-ibu penggerak Desa Cileles yang saat ini rutin dilakukan adalah posyandu dan pelayanan kesehatan ibu dan anak. Program posyandu dimaksudkan untuk mencegah stunting dan meningkatkan tumbuh kembang balita dan anak-anak (Hayati et al. 2015).

Masyarakat Desa Cileles sebagaimana masyarakat Jawa Barat umumnya, tingkat konsumsi pangan ikan masih rendah dibandingkan dengan rata-rata nasional, terutama dari kelompok balita dan anak-anak. Menurut Kepala Disnas Perikanan Jawa Barat, konsumsi pangan ikan masyarakat Jawa Barat pada tahun 2019 
sebanyak $26 \mathrm{~kg} / \mathrm{kapita} /$ tahun, lebih rendah dibandingkan konsumsi pangan ikan nasional yaitu sebanyak 50,95 kg/kapita/tahun. Hal ini disebabkan pengolahan ikan yang dilakukan oleh masyarakat Jawa Barat masih sederhana misalnya hanya dipepes dan digoreng (Anef 2019). Oleh karena itu, perlu adanya upaya peningkatan konsumsi ikani melalui peanganekaragaman pengolahan ikan. Konsumsi protein ikan sangat penting artinya dalam upaya menjaga kesehatan, mempercepat tumbuh kembang anak, dan peningkatan kecerdasan (Prameswari 2018).

Peningkatan konsumsi ikani dapat dilakukan dengan diversifikasi pengolahan ikan, terutama produk-produk olahan ikan yang disukai oleh anak-anak dan balita (Dotulong \& Montolalu 2019). Diversifikasi dapat dilakukan dengan cara subsitusi dan suplementasi (Faroj 2019). Penambahan atau suplementasi tepung ikan pada biskuit adalah salah satu alternatif untuk meningkatkan konsumsi ikan. Menurut Muslihah et al. (2016), biskuit merupakan salah satu makanan pendamping air susu ibu (ASI).

Pengetahuan dan keterampilan masyarakat dalam hal pembuatan biskuit masih rendah, sehingga perlu adanya pendidikan. Penyuluhan adalah salah satu bentuk pendidikan yang dapat dilakukan kepada masyarakat untuk meningkatkan pengetahuan dan keterampilannya (Nurdin 2014). Metode penyuluhan yang tepat untuk dilakukan adalah melalui tiga tahapan yaitu diskusi, workshop, dan pendampingan. Mitra strategis dalam kegiatan penyuluhan ini adalah ibu-ibu penggerak desa yang berkecimpung dalam program posyandu.

Pendidikan mempunyai peranan penting dalam aspek kehidupan masyarakat. Menurut Norkholis (2013), pendidikan merupakan media strategis dalam mengatasi berbagai problem yang dihadapi masyarakat dan meningkatkan kualitas keberlangsungan hidupnya. Oleh karena itu, tujuan program ini untuk memberikan pengetahuan dan melatih keterampilan dalam pembuatan biskuit kaya protein ikan yang difortifikasi dengan tepung daging ikan nilem kepada ibu-ibu posyandu sebagai khalayak sasaran di Desa Cileles, Kecamatan Jatinangor, Kabupaten Sumedang. Harapan selanjutnya adalah adanya peningkatan asupan gizi protein ikan bagi balita dan anak-anak khususnya di Desa Cileles melalui pemberian makanan tambahan biskuit kaya protein ikan melalui program kegiatan posyandu.

\section{METODE PELAKSANAAN KEGIATAN}

\section{Lokasi dan Partisipan}

Pelaksanaan kegiatan ini dilakukan di saung kolam budi daya ikan "Ciparanje" milik Unpad. Tempat ini berlokasi di Rt 01 RW 4, Desa Cileles, Kecamatan Jatinangor, Kabupaten Sumedang, Jawa Barat. Partisipan atau khalayak sasaran kegiatan ini adalah ibu-ibu penggerak Desa Cileles yang aktif dalam kegiatan posyandu. Jumlah peserta pelatihan sebanyak 10 orang yang tersebar dalam 10 RW dan 36 RT di Desa Cileles.

\section{Bahan dan alat}

Bahan yang digunakan antara lain tepung daging ikan nilem karena mengandung protein tinggi sebesar $78,8 \%$ dan kalsium yang tinggi pula sebesar $0,11 \%$ (Junianto et al. 2020), tepung terigu, tepung gula, susu bubuk, baking powder, dan mentega. Alat-alat yang digunakan adalah oven, nampan aluminium, mixer, baskom plastic, dan cetakan biskuit. Alat lainya adalah LCD, laptop, dan materi prosedur pembuatan biskuit.

\section{Bentuk Kegiatan}

Bentuk kegiatan yang digunakan adalah pelatihan tentang pembuatan biskuit yang difortifikasi dengan tepung daging ikan nilem. Pelatihan ini diawali dengan penyampaian materi atau pengetahuan tentang a) Prosedur pembuatan biskuit yang difortifikasi dengan tepung daging ikan nilem; b) Pentingnya asupan protein ikan untuk anak-anak; dan c) Pentingnya diversikasi olahan ikan untuk meningkatkan konsumsi ikan. Teknik penyampaian materi yang digunakan adalah ceramah. Kegiatan ceramah ini dilakukan pada tanggal 19 Oktober 2020 di saung penyuluhan Ciparanje, milik Fakultas Perikanan dan Ilmu Kelautan Unpad.

Tahap berikutnya adalah pembuatan biskuit yang difortifikasi dengan tepung daging ikan nilem. Proses pembuatan biskuit menurut Afriani et al. (2016) yang dimodifikasi adalah sebagai berikut: a) Telur, gula, dan mentega dikocok sampai mengembang selama 15 menit hingga homogeny; b) Tepung terigu, vanili, baking powder, dan susu kental dicampurkan ke dalam adonan; c) Tepung daging ikan nilem dicampurkan ke dalam adonan; dan d) Adonan dicetak dan dipanggang dalam oven $150^{\circ} \mathrm{C}$ selama 17 menit.

Untuk mengetahui daya terima peserta terhadap materi yang disampaikan tersebut maka 
data yang diambil adalah skor kuesioner yang diberikan kepada peserta sebelum dan setelah ceramah. Selanjutnya untuk mendapatkan gambaran keberhasilan keterampilan peserta dalam membuat biskuit yang difortifikasi dengan tepung daging ikan nilem, data diambil dari skor penilaian tingkat kesukaan produk biskuit kaya protein yang dihasilkan. Penilaian tingkat kesukaan produk biskuit tersebut diuji dengan uji hedonik (Gambar 1). Panelis yang digunakan sebanyak 20 orang, 10 orang peserta pelatihan, 3 orang tim pelaksan kegiatan, dan 7 orang asisten pelaksana (Mahasiswa Program Studi Perikanan Unpad semester 7). Semua data yang diperoleh dianalis secara diskriptif.

\section{HASIL DAN PEMBAHASAN}

\section{Penyampaian Informasi tentang Biskuit Kaya Protein}

Teknik yang paling ekonomis untuk menyampaikan informasi kepada khalayak sasaran adalah melalui ceramah (Malia \& Rahayu 2014). Ceramah didefinisikan sebagai penyampaian pengetahuan kepada khalayak sasaran langsung bertatap muka, dan peserta pada umumnya mengikuti secara pasif (Ramadhan 2014). Penyampaian informasi melalui ceramah ini berlangsung sangat menarik dan atraktif. Peserta sangat antusias karena pemberi materi menyampaikan dengan penuh keakraban. Peserta merasa tidak digurui dan materi yang disampaikan memang benar-benar diperlukan. Kelakar yang jenaka sesekali dilontarkan untuk memberikan suasana yang tidak menoton dan membosankan. Setelah penyampaian materi ada diskusi atau tanya jawab. Peserta banyak sekali yang bertanya, hampir semua peserta bertanya. Pertanyaan yang diajukan sangat variatif mulai dari apa manfaat protein bagi tubuh sampai pembandingan harga jika proteinnya bersumber dari non ikan.

Ceramah diawali dengan penyampaian kuesioner yang berisi 10 pertanyaan (Gambar 2) terkait dengan materi ceramah, yaitu prosedur pembuatan biskuit, pentingnya asupan protein ikan untuk anak-anak, dan diversifikasi olahan ikan. Kuesioner dengan pertanyaan yang sama juga diberikan setelah ceramah selesai. Skor hasil kuesioner ini terdapat pada Tabel 1.

Tabel 1 menunjukkan adanya peningkatan skor kuesioner yang diperoleh peserta pelatihan setelah ceramah dibandingkan dengan sebelum ceramah. Artinya materi yang telah disampaikan mampu meningkatkan pengetahuan semua

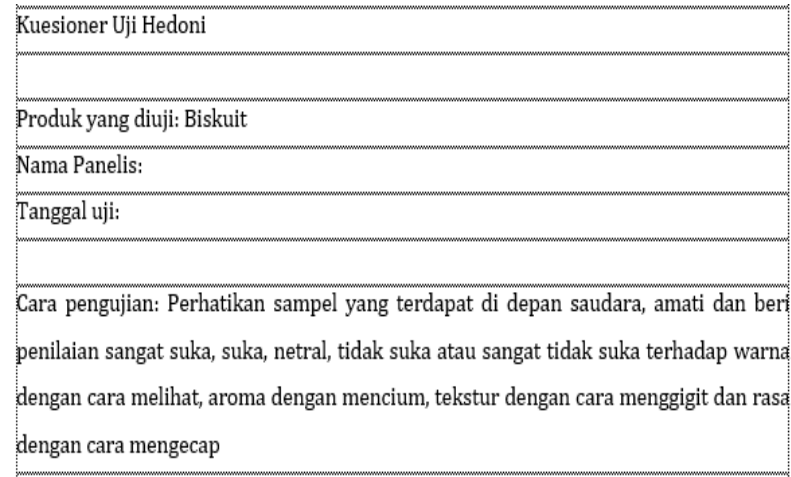

Gambar 1 Kuesioner uji hedoni.

\begin{tabular}{|c|}
\hline Kuesioner pre-test dan post-test \\
\hline Pilihah jawaban yang paling benar dengan cara melingkari \\
\hline 1. Salah satu bahan yang digunakan dalam pembuatan biskuit adalah \\
\hline a. bawang putih, b. bawang merah c. ketumbar d. gula \\
\hline 2. salah satu tahapan dalam pembuatan biskuit adalah \\
\hline a. dijemur di terik sinar matahari b. didinginkan dalam lemari es \\
\hline c. di keringkan dalam oven. d. semua jawaban benar \\
\hline 3. Tepung yang digunakan dalam pembuatan biskuit adalah \\
\hline a. tepung aci, b. tepung jagung c. tepung kedelai d. tepung terigu \\
\hline 4. Daging ikan nilem banyak mengandung gizi \\
\hline a. lemak b. protein c. karbohidrat d. semua salah \\
\hline 5. Protein sangat berguna untuk tubuh sebagai \\
\hline a. sumber energi b. pengganti dan pembangun sel tubuh \\
\hline c. biokatalisator $d$ semua benar \\
\hline 6. Asupan protein anak-anak dan belita \\
\hline a. tidak begitu perlu b. biasa-biasa saja c. sangat perlu d. tidak tahu \\
\hline 7. Ikan nilem dapat diolah menjadi \\
\hline a. tepung daging ikan b. tepung konsentrat perotein ikan \\
\hline c. tepung hidrolisat protein ikan d. semua betul \\
\hline 8. Makanan berikut dapat dibuat dari daging ikan \\
\hline a. bakso, b. nugget c. sosis d. semua betul \\
\hline $\begin{array}{l}\text { 9. Pengolahan ikan yang mengunakan sinar matahari dalam pengeringannya } \\
\text { adalah }\end{array}$ \\
\hline a. Ikan asin b. semur ikan c. pepes ikan d. tidak tahu \\
\hline 10.Ikan nilem banyak diolah menjadi \\
\hline a. dipindang b. dibuat petis c. dibuat terasi d. dibuat kerupuk \\
\hline
\end{tabular}

Gambar 2 Kuesioner pre-test dan post-test.

Tabel 1 Perolehan skor kueseioner peserta pelatihan sebelum dan sesudah ceramah

\begin{tabular}{cccc}
\hline & \multicolumn{2}{c}{ Skor } & Sebelum \\
ceramah & $\begin{array}{c}\text { Sesudah } \\
\text { ceramah }\end{array}$ & $\begin{array}{c}\text { Peningkatan } \\
\text { skor (\%) }\end{array}$ \\
\hline Maksimal & 45 & 95 & 111 \\
Minimal & 20 & 70 & 250 \\
Rata-rata & 35 & 80 & 129 \\
\hline
\end{tabular}

peserta terkait dengan pembuatan biskuit, pentingnya asupan protein ikan untuk anak-anak dan pentingnya diversifikasi olahan ikan. Ratarata peningkatan skor kuesioner yang diperoleh peserta pelatihan setelah ceramah dibandingkan dengan sebelum ceramah sebesar 129\% (Tabel 1). Peningkatan pengetahuan yang sangat besar ini karena beberapa faktor di antaranya sebagian besar peserta berpendidikan SLTA dan memiliki keinginan kuat untuk berubah. Menurut Dharmawati \& Wirata (2016), daya terima hasil pembelajaran seseorang dapat dipengaruhi oleh 
beberapa faktor, yaitu pengalaman, umur, dan pendidikan.

\section{Pembuatan Biskuit Kaya Protein Ikani}

Kegiatan berikutnya setelah penyampaian informasi tentang prosedur pembuatan biskuit adalah kegiatan praktik/demo. Menurut Imran et al. (2019), demo merupakan salah satu cara yang biasa digunakan dalam kegiatan penyuluhan selain ceramah. Kegiatan demo ini bermaksud untuk melatih skill pembuatan biskuit. Kegiatan demo terlihat pada Gambar 3. Berdasarkan Gambar 4 tampak peserta dengan seksama memerhatikan teknik pemipihan adonan. Peserta memiliki keingin tahuan yang sangat tinggi untuk dapat melakukan pembuatan biskuit. Semua peserta merasa senang dapat mempraktikkan langsung pembuatan biskuit.

Proses pelaksanaan kegiatan demo tidak mengalami hambatan yang berarti. Hal ini karena semua peserta memiliki motivasi yang kuat untuk dapat membuat biskuit dengan baik. Menurut Sugiarta et al. (2017), motivasi kerja berkorelasi positif dengan keberhasilan outputnya. Peserta pelatihan dalam kegiatan demo ini dapat melihat dan menerapkan secara langsung informasi yang diperolehnya. Demo telah memberikan banyak tambahan pengetahuan dan keterampilan peserta dalam proses pembuatan biskuit yang difortifikasi dengan tepung daging ikan nilem.

Menurut hasil penelitian Wibowo et al. (2018), pembelajaran dengan cara demo memberikan hasil yang baik dengan skor 3,82 dalam penyampaian pesan kepada khalayak sasaran. Oleh karena itu, dalam kegiatankegiatan pelatihan yang dilakukan, demo selalu menjadi teknik prioritas agar pesan yang ingin disampaikan tercapai.

Kegiatan berikutnya setelah demo adalah kerja mandiri. Bedanya dengan demo adalah peserta secara aktif membuat biskuit. Kerja mandiri bertujuan agar peserta dapat lebih meningkatkan keterampilannya dalam pembuatan biskuit. Kegiatan mandiri pembuatan biskuit ini tampak pada Gambar 4a. Hasil produk biskuit yang diperolehnya sebagaimana pada Gambar 4b. Biskuit yang dihasilkan dilakukan penilaian terhadap tingkat kesukaannya. Panelisnya adalah para peserta pelatihan, tim pelaksana, dan asisten pelaksana, semuanya berjumlah 20 panelis. Penilaian tingkat kesukaan panelis terhadap warna, rasa, aroma, dan tekstur biskuit yang difortifikasi dengan tepung daging ikan nilem terdapat pada Tabel 2 .

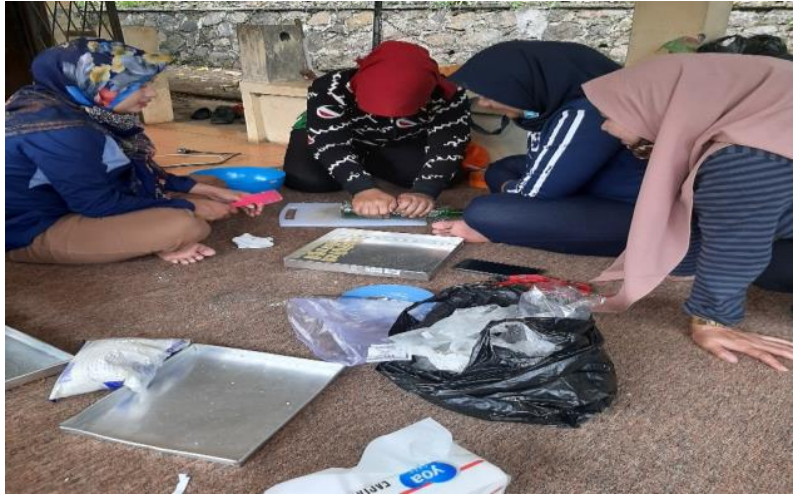

Gambar 3 Praktik teknik pemipihan adonan dalam kegiatan demplot bersama pelatih.

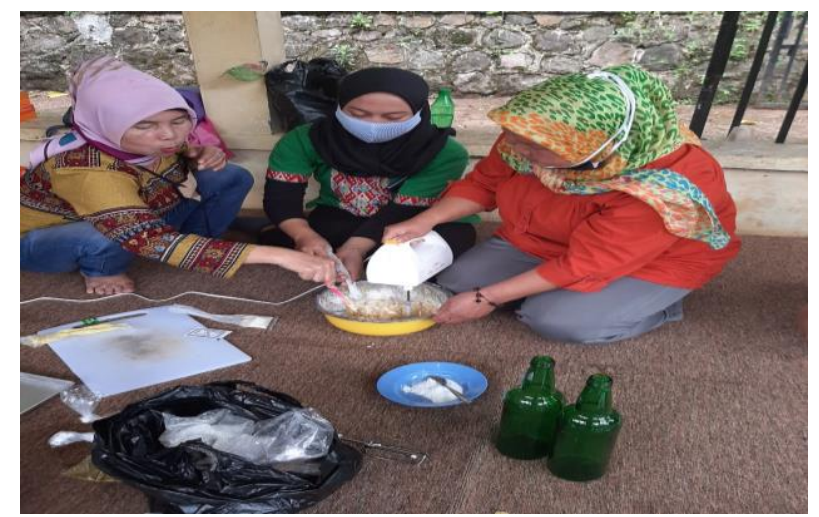

$\mathrm{a}$

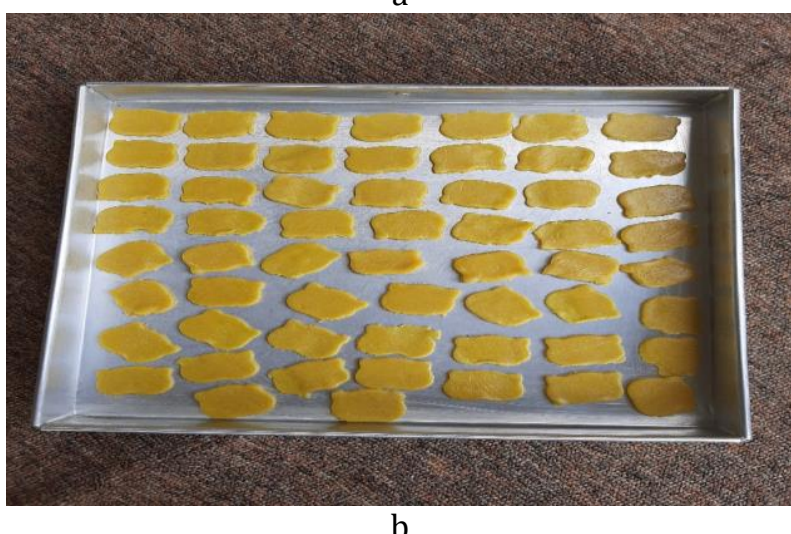

Gambar 4 a) Peserta membuat adonan biskuit pada kegiatan mandiri dan b) Hasil biskuit pada

Berdasarkan Tabel 2, biskuit kaya protein ikan yang diproduksi oleh peserta sebagian besar disukai baik rasa, warna, tekstur, maupun flavor, dan bahkan semua panelis menyatakan suka terhadap warna biskuit yang dihasilkan. Hal ini dapat dinyatakan bahwa skill peserta pelatihan dalam pembuatan biskuit telah ada peningkatan, dari yang semula belum dapat membuat menjadi dapat membuat biskuit dengan sifat organoleptiknya yang disukai oleh panelis. Biskuit yang dihasilkan tersebut kemungkinan dapat diterima atau disukai juga oleh anak-anak dan balita, karena panelis yang sebagian besar ibu- 
Tabel 2 Skor sebaran panelis terhadap tingkat kesukaan biskuit kaya protein ikan

\begin{tabular}{lcccc}
\hline \multicolumn{1}{c}{ Penilaian (\%) } & \multicolumn{2}{c}{ Parameter } & Flavour \\
\hline Sangat suka & 10 & Warna & Tekstur & 0 \\
Suka & 80 & 0 & 70 & 80 \\
Biasa & 10 & 0 & 30 & 20 \\
Tidak suka & 0 & 0 & 0 & 0 \\
Sangat tidak suka & 0 & 0 & 0 & 0 \\
\hline
\end{tabular}

ibu memiliki peran besar dalam memengaruhi tingkat kesukaan balita.

Penentuan waktu pelatihan dan kondisi pandemi Covid 19 menjadi kendala dalam pelaksanaan kegiatan ini. Ibu-ibu penggerak Desa Cileles yang aktif dalam kegiatan posyandu ini memiliki banyak aktivitas, sehingga perlu pengaturan waktu yang sesuai dalam pelaksanaan kegiatan ini. Kondisi pandemi Covid 19 tidak memberikan keleluasaan dalam berinteraksi antar peserta dan pelaksana kegiatan, yang dampaknya kurang optimal dalam limpah keterampilan pembuatan biskuit.

\section{Keberlanjutan Program}

Berdasarkan produk biskuit yang dihasilkan dari kegiatan ini, nampaknya perlu adanya keberlanjutan program. Program lanjutannya adalah bekerja sama dengan pemerintahan Desa Cileles agar biskuit kaya protein ikan diproduksi secara regular, dijadikan makanan tambahan pendamping ASI untuk anak-anak balita. Tidak ada salahnya untuk ke depan, pembuatan biskuit kaya protein ikan ini dijadikan suatu usaha home industri milik desa (Bumdes) yang terintegrasi dengan usuha budi daya ikan nilem, industri tepung ikan nilem, dan pemanfaatan limbah dari industri tepung daging seperti kulit dan tulang serta telur nilem. Oleh karena itu, sanitasi dan hiegienitas produk perlu diintroduksikan berikut dengan tahapan-tahapan perijinanan serta manajemen industrinya.

\section{SIMPULAN}

Pengetahuan dan keterampilan ibu-ibu posyandu dalam pembuatan biskuit kaya protein ikani yang difortifikasi dengan tepung daging ikan nilem telah ada peningkatan. Produk yang dihasilkan secara organoleptik disukai oleh panelis.

\section{DAFTAR PUSTAKA}

Afriani RR, Kurniawati N, Rostini I. 2016. Penambahan konsentrat protein ikan nila terhadap karakteristik kimia dan organoleptik biskuit. Jurnal Perikanan Kelautan. VII(1): 613.

Anef. 2019. Konsumsi ikan masyarakat jawa barat masih rendah. [Internet]. [Diakses pada: 26 Agustus 2021]. Tersedia pada: https://www.pikiran-rakyat.com/jawabarat/pr-01310821/konsumsi-ikanmasyarakat-jawa-barat-masihrendah?page $=2$

Dharmawati IGAA, Wirata IY. 2016. Hubungan tingkat pendidikan, umur, dan masa kerja dengan tingkat pengetahuan kesehatan gigi dan mulut pada guru penjakes SD di Kecamatan Tampak Siring Gianyar. Jurnal Kesehatan. 4(1): 1-5.

Dotulong V, Montolalu LADY. 2019. PKM tentang pengolahan nugget dan kaki naga ikan pada kelompok wanita kaum ibu (WKI) GMIM solafide Kelurahan Girian Indah, Kecamatan Girian, Kota Bitung, Provinsi Sulawesi Utara. Jurnal Media Teknologi Hasil Perikanan. 7(3): 88-92. https://doi.org/10.35800/mthp. 7.3.2019.24368

Faroj MN. 2019. Pengaruh subsitusi tepung ikan teri (Stolephorus commersonii) dan tepung kacang merah (Vigna angularis) terhadap daya terima dan kandungan protein pie mini. Media Gizi Indonesia. 14(1): 56-65. https:// doi.org/10.20473/mgi.v14i1.56-65

Hayati DN, Muthmainnah, Fayimaningrum AS. 2015. Pelatihan kader posyandu dalam deteksi perkembangan anak usia dini. Jurnal Pendidikan Anak. IV(2): 651-658. https:// doi.org/10.21831/jpa.v4i2.12359 
Imran AN, Muhanniah, Giono BRW. 2019. Metode penyuluhan pertanian dalam meningkatkan pengetahuan dan keterampilan petani (Studi kasus di Kecamatan Maros Baru Kabupaten Maros). Jurnal Agrisep. 18(2): 289-304. https://doi.org/10.31186/jagrisep.18.2.289304

Junianto, Afrianto E, Zahidah. 2020. Perancangan proses dan karakterisasi produk olahan berbahan baku ikan nilem sebesar. Laporan akhir penelitian dasar. Bandung(ID): Universitas Padjadjaran.

Malia R, Rahayu LS. 2014. Pengaruh penyuluhan melalui metode ceramah dan diskusi terhadap tingkat pengetahuan teknologi sistem tanam legowo di Kelompok Tani Karya Mukti III Desa Sukakarya Kecamatan Sukanagara Kabupaten Cianjur. Jurnal Agroscience. 7: 51-60.

Muslihah N, Khomsan A, Briawan D, Riyadi H. 2016. Kepatuhan konsumsi suplemen gizi berbasis lipid di Perdesaan, Kabupaten Bangkalan. Jurnal Gizi Pangan. 11(2): 115124.

Norkholis. 2013. Pendidikan dalam upaya memajukan teknologi. Jurnal Kependidikan. 1(1): 24-44. https://doi.org/10. 24090/jk.v1i1.530

Nurdin. 2014. Pengaruh metode penyuluhan dan tingkat pendidikan terhadap pengetahuan berwawasan lingkungan. Jurnal Ilmu Pendidikan. 20(2): 201-206.

Prameswari GN. 2018. Promosi gizi terhadap sikap gemar makan ikan pada anak usia sekolah. Journal of Health Education. 3(1): 16. https://doi.org/10.36565/jak.v1i1.3

Ramadhan ES. 2014. Efektifitas metode ceramah dan bermain dalam penyuluhan kesehatan gigi dan mulut terhadap pengetahuan siswa/i SDN 064926 Ladang Bambu Medan Tuntungan. Jurnal Ilmiah PANNMED. 8(3): 267-271. https://doi.org/10.36911/ pannmed.v8i3.368

Sugiarta P, Ambarawati IGAA, Putra IGSA. 2017. Pengaruh kinerja penyuluh pertanian terhadap perilaku petani dan penerapan teknologi PTT dan produkrivitas padi di Kabupaten Beleleng. Jurnal Manajemen Agribisnis. 5(2): 34-42. https://doi.org/ 10.24843/JMA.2017.v05.i02.p06

Wibowo HS, Sutjipta N, Windia IW. 2018. Peranan penyuluh pertanian lapangan (PPL) sebagai hasilitator dalam penggunaan metode belajar pendidikan orang dewasa (Andragogi) (Kasus di gapoktan madani, Desa Sampalan Klod, Kecamatan Dawan, Kabupaten Klungkung, Provinsi Bali). Jurnal Agribisnis dan Agrowisata. 7(1): 21-30. https://doi. org/10.24843/JAA.2018.v07.i01.p03 